\title{
Accumulation of cadmium from wheat bran, sugar-beet fibre, carrots and cadmium chloride in the liver and kidneys of mice
}

\author{
Ylva Lind ${ }^{1,2}$, Joakim Engman ${ }^{1}$, Lars Jorhem ${ }^{1}$ and Anders Wicklund Glynn ${ }^{1,2}$ \\ ${ }^{1}$ The Swedish National Food Administration, Box 622, S-751 26 Uppsala, Sweden \\ ${ }^{2}$ Department of Environmental Toxicology, Uppsala University, Norbyvägen 18A, S-752 36 Uppsala, Sweden
}

(Received 16 June 1997 - Revised 10 February 1998 - Accepted 18 February 1998)

\begin{abstract}
The gastrointestinal absorption and organ distribution of Cd after exposure for 9 weeks to three fibre-rich foodstuffs (wheat bran, sugar-beet fibre and carrots) were determined in mice. Groups of eight mice were given a diet containing $0.05 \mathrm{mg} \mathrm{Cd} / \mathrm{kg}$ from wheat bran, sugar-beet fibre, carrots or $\mathrm{CdCl}_{2}$ mixed in a semi-synthetic, low-Cd $(<0.007 \mathrm{mg} / \mathrm{kg})$ feed. A control group was fed on the low-Cd semi-synthetic feed. The water consumption, food consumption and the weight of the animals were monitored throughout the study. The feed was changed once weekly and $\mathrm{Cd}$ was analysed in the feed at each change. myo-Inositol phosphates (hexa-, penta-, tetra- and tri-) and $\mathrm{Zn}, \mathrm{Cu}, \mathrm{Fe}$ and $\mathrm{Ca}$ were also analysed in the diets. After 9 weeks, the mice were killed and liver and kidneys were sampled and analysed for $\mathrm{Cd}$. The group receiving the wheat-bran diet had significantly lower fractional $\mathrm{Cd}$ accumulation (\% total $\mathrm{Cd}$ intake) in the liver and kidneys than the other groups, indicating a lower fractional absorption of $\mathrm{Cd}$. The wheat-bran diet had markedly higher levels of inositol hexa- and pentaphosphates (phytates) and a $\mathrm{Zn}$ level that was twice as high as those in the other diets. The higher levels of myo-inositol hexa- and pentaphosphates in the wheat-bran diet most probably contributed more to the lower fractional absorption of $\mathrm{Cd}$ than the elevated $\mathrm{Zn}$ level, due to the formation of insoluble $\mathrm{Cd}$-phytate complexes. Compared with the wheat-bran diet, the sugar-beet-fibre and carrot diets contained very low levels of myo-inositol penta- and hexaphosphates, and consequently the fractional $\mathrm{Cd}$ absorption from these diets was higher.
\end{abstract}

Intestinal absorption: Inositol phosphates: Dietary fibre: Trace elements

During recent decades the use of fertilizers with high $\mathrm{Cd}$ concentrations has led to an increased Cd level in the soil in many areas of Sweden (Kjellström et al. 1975; Andersson \& Bingefors, 1985; Andersson \& Siman, 1991). Cereals such as wheat, together with root crops, such as potatoes and carrots, accumulate $\mathrm{Cd}$, and these foodstuffs contribute a large part of the daily $\mathrm{Cd}$ intake (Nilsson \& Wallgren, 1987). These foodstuffs are also important sources of dietary fibre and a high consumption may be positive for health. A drawback with a high vegetable-fibre intake might be, however, that dietary fibres could lower the absorption of essential minerals (Kratzer \& Vohra, 1986). Furthermore, the parts of vegetables and cereals containing the fibres could also have a relatively high level of $\mathrm{Cd}$. Thus, a high intake of fibre-rich foodstuffs might result in an elevated intake of Cd (Berglund et al. 1994).

Sugar-beet fibre has been proposed as an alternative to wheat bran as a dietary fibre source, due to experimental findings that sugar-beet fibre, in contrast to fibre from wheat bran, might in some cases increase the absorption of $\mathrm{Fe}$ and
Zn (Fairweather-Tait \& Wright, 1990). However, a problem with commercial sugar-beet-fibre preparations is that they may contain high levels of $\mathrm{Cd}$ (up to $0.6 \mathrm{mg} \mathrm{Cd} / \mathrm{kg}$; Y Lind, J Engman, L Jorhem and A Wicklund Glynn, unpublished results). Moreover, based on the findings of an enhanced mineral absorption in rats fed on sugar-beet fibre, it may be hypothesized that the absorption of endogenous $\mathrm{Cd}$ in the sugar-beet fibre may be high in comparison with that of $\mathrm{Cd}$ in wheat bran containing high levels of phytate. It is known that the presence of high concentrations of inositol hexaphosphate $\left(\mathrm{IP}_{6}\right.$; phytate) in fibre-rich wheat bran may lower the absorption of Cd (Buhler, 1985; Moberg Wing, 1993).

The comparison of intestinal $\mathrm{Cd}$ absorption from two important fibre sources such as wheat bran and sugar-beet fibre has not been made before. The purpose of the present study was to elucidate the absorption of $\mathrm{Cd}$ from the two fibre sources compared with that of carrots and $\mathrm{CdCl}_{2}$. The study was carried out in mice according to an experimental design used in an earlier study (Lind et al. 1995). 


\section{Materials and methods}

\section{Animals}

Newly-weaned, female Balb c mice were purchased from Bomholt, Ry, Denmark. They were acclimatized in wiremesh cages and had free access to a semi-synthetic control feed ( $<0.007 \mathrm{mg} \mathrm{Cd} / \mathrm{kg}$; AnalyCen, Lidköping, Sweden) and tap water for 1 week before the start of the experiment. The mice were maintained at $23^{\circ}, 50-60 \%$ humidity and a $12 \mathrm{~h}-12 \mathrm{~h}$ light-dark cycle. Principles of laboratory animal care were followed and the animal experiments were approved by the Uppsala Ethics Committee of Animal Experiments (permit no. C 249/3).

\section{Diets}

Carrots were obtained from Ingrid Öborn, Department of Soil Sciences, Swedish University of Agricultural Sciences,

Table 1. The composition $(\mathrm{g} / \mathrm{kg})$ of the different diets*

\begin{tabular}{lrccrr}
\hline Diet... & Control & Wheat bran & Sugar-beet fibre & Carrot & $\mathrm{CdCl}_{2}$ \\
\hline Protein & 177 & 182 & 176 & 169 & 183 \\
Fat & 44 & 72 & 68 & 68 & 70 \\
NFE & 629 & 615 & 632 & 629 & 641 \\
Ash & 18 & 24 & 21 & 26 & 21 \\
Fibre & 4 & 16 & 15 & 13 & 4 \\
Water & 128 & 91 & 88 & 95 & 81 \\
\hline
\end{tabular}

$\mathrm{NFE}, \mathrm{N}$-free extraction products (carbohydrates).

${ }^{*}$ For details of diets, see p. 206.
Uppsala, Sweden. Wheat bran (provided by Cerealia, Malmö, Sweden) was of Canadian origin.

Sugar-beet fibre, (Fibrex ${ }^{\text {iW }}$; Sockerbolaget, Sweden) was purchased in a local store. The raw carrots were washed, cut into slices and freeze-dried. The wheat bran, sugar-beet fibre and freeze-dried carrots were finely chopped using titanium knives and analysed for $\mathrm{Cd}$. The $\mathrm{Cd}$ levels in the different components were: wheat bran, $0.31 \mathrm{mg} \mathrm{Cd} / \mathrm{kg}$ dry weight; sugar-beet fibre, $0.65 \mathrm{mg} \mathrm{Cd} / \mathrm{kg}$ dry weight; and carrots, $0.46 \mathrm{mg} \mathrm{Cd} / \mathrm{kg}$ dry weight. The components were mixed into the semi-synthetic control feed to a nominal $\mathrm{Cd}$ level of $0.05 \mathrm{mg} / \mathrm{kg}$. Samples were taken and analysed for $\mathrm{Cd}$ before the feed was pelleted, to check the $\mathrm{Cd}$ level and homogeneity of the different diets: diet 1 , control diet (semi-synthetic feed); diet 2, wheat bran to a total content of $161 \mathrm{~g} / \mathrm{kg}$; diet 3, sugar-beet fibre to a total content of $77 \mathrm{~g} / \mathrm{kg}$; diet 4, freeze-dried carrots to a total content of $109 \mathrm{~g} / \mathrm{kg}$; diet $5, \mathrm{CdCl}_{2} \cdot 2 \cdot 5 \mathrm{H}_{2} \mathrm{O}$ (analytical grade; Merck, Darmstadt, Germany). The final composition of the different diets is shown in Table 1. The diets were also analysed for $\mathrm{Cd}, \mathrm{Zn}, \mathrm{Cu}, \mathrm{Fe}, \mathrm{Ca}$ (Table 2) and inositol phosphates (Table 3).

\section{Experimental design}

The mice were randomly divided into five groups with eight mice in each group. They were kept in plastic cages with wire-mesh floors (four mice per cage). At the start of the experiment the mice were weighed and each group was given its special diet. The mice were weighed

Table 2. The level of cadmium and some other minerals $(\mathrm{mg} / \mathrm{kg})$ in the different diets*

(Values are medians with ranges for nine to ten determinations)

\begin{tabular}{|c|c|c|c|c|c|}
\hline Diet... & Control & Wheat bran & Sugar-beet fibre & Carrot & $\mathrm{CdCl}_{2}$ \\
\hline $\begin{array}{l}\text { Cd: Median } \\
\text { Range }\end{array}$ & $<0.008$ & $\begin{array}{l}0.056 \\
0.051-0.066\end{array}$ & $\begin{array}{l}0.044 \\
0.035-0.048\end{array}$ & $\begin{array}{l}0.042 \\
0.039-0.049\end{array}$ & $\begin{array}{l}0.050 \\
0.044-0.059\end{array}$ \\
\hline $\begin{array}{c}\text { Zn: Median } \\
\text { Range }\end{array}$ & $\begin{array}{l}9.72 \\
7.63-15.6\end{array}$ & $\begin{array}{l}24 \cdot 4 \\
23 \cdot 2-25 \cdot 7\end{array}$ & $\begin{array}{l}11 \cdot 0 \\
10 \cdot 0-12 \cdot 2\end{array}$ & $\begin{array}{l}14 \cdot 4 \\
14 \cdot 1-14 \cdot 8\end{array}$ & $\begin{array}{l}9.76 \\
9.36-10.8\end{array}$ \\
\hline $\begin{array}{c}\text { Cu: Median } \\
\text { Range }\end{array}$ & $\begin{array}{l}8.63 \\
7.81-9.53\end{array}$ & $\begin{array}{l}9.23 \\
7.95-11.1\end{array}$ & $\begin{array}{l}8.02 \\
7.3-9.07\end{array}$ & $\begin{array}{l}9.07 \\
7.33-10.4\end{array}$ & $\begin{array}{l}8.99 \\
8.05-10.8\end{array}$ \\
\hline $\begin{array}{l}\text { Fe: Median } \\
\text { Range }\end{array}$ & $\begin{array}{l}75 \cdot 7 \\
55 \cdot 7-90 \cdot 7\end{array}$ & $\begin{array}{l}69.9 \\
60.9-83.9\end{array}$ & $\begin{array}{l}74.5 \\
72 \cdot 7-83 \cdot 1\end{array}$ & $\begin{array}{l}84.9 \\
72 \cdot 9-99.8\end{array}$ & $\begin{array}{l}63 \cdot 1 \\
57 \cdot 0-80 \cdot 8\end{array}$ \\
\hline $\begin{array}{c}\text { Ca: Median } \\
\text { Range }\end{array}$ & $\begin{array}{l}3038 \\
2872-3141\end{array}$ & $\begin{array}{l}2592 \\
2456-2666\end{array}$ & $\begin{array}{l}3720 \\
3692-3873\end{array}$ & $\begin{array}{l}3310 \\
3098-3433\end{array}$ & $\begin{array}{l}3120 \\
3066-3262\end{array}$ \\
\hline
\end{tabular}

${ }^{*}$ For details of diets, see p. 206 and Table 1.

Table 3. The concentration ( $\mu \mathrm{mol} / \mathrm{g}$ dry weight) of inositol triphosphate (IP3), inositol tetraphosphate (IP4), inositol pentaphosphate (IP5) and inositol hexaphosphate (IP6) in the different diets*

(Values are means for two determinations)

\begin{tabular}{lcccc}
\hline Diet... & Control and $\mathrm{CdCl}_{2}$ & Wheat bran & Sugar-beet fibre & Carrot \\
\hline IP3 & nd & nd & 0.10 & 0.07 \\
IP4 & nd & 0.05 & 0.06 & 0.04 \\
IP5 & nd & 0.29 & nd & $\dagger$ \\
IP6 & nd & 6.39 & nd & 0.18 \\
\hline
\end{tabular}

nd, No detectable levels.

* For details of diets, see p. 206 and Tables 1 and 2.

†Traces, detection limit for IP3-IP6 approximately $0.01 \mu \mathrm{mol} / \mathrm{g}$ dry wt. 
Table 4. Results of the analysis of certified materials and a comparison with the certified levels (mg/kg dry weight)* (Means and standard deviations for the no. of analyses shown in parentheses. The certified results are means and $95 \% \mathrm{Cl}$ )

\begin{tabular}{|c|c|c|c|c|c|c|}
\hline & \multicolumn{2}{|c|}{ Simulated diet A† (6) } & \multicolumn{2}{|c|}{ Simulated diet $\mathrm{D} \dagger(4)$} & \multicolumn{2}{|c|}{ Bovine liver no. 1577bł (18) } \\
\hline $\begin{array}{l}\text { Cd: Found } \\
\text { Certified }\end{array}$ & $\begin{array}{l}0.0280 \\
0.029\end{array}$ & $\begin{array}{l}0.002 \\
0.003\end{array}$ & $\begin{array}{l}0.449 \\
0.478\end{array}$ & $\begin{array}{l}0.025 \\
0.026\end{array}$ & $\begin{array}{l}0.52 \\
0.50\end{array}$ & $\begin{array}{l}0.04 \\
0.03\end{array}$ \\
\hline $\begin{array}{l}\text { Zn: Found } \\
\text { Certified }\end{array}$ & $\begin{array}{l}99.4 \\
95.0\end{array}$ & $\begin{array}{l}2.6 \\
4.5\end{array}$ & & & & \\
\hline $\begin{array}{l}\text { Cu: Found } \\
\text { Certified } \\
\text { Fe: Found } \\
\text { Certified }\end{array}$ & $\begin{array}{c}2.58 \\
2.60 \\
88.9 \\
81.2\end{array}$ & $\begin{array}{l}0.26 \\
0.15 \\
3.0 \\
4.8\end{array}$ & & & & \\
\hline $\begin{array}{l}\text { Ca: Found } \\
\text { Certified }\end{array}$ & $\begin{array}{l}1665 \\
1576\end{array}$ & $\begin{array}{r}24 \\
104\end{array}$ & & & & \\
\hline
\end{tabular}

* For details of procedures, see p. 207.

†From The Swedish National Food Administration (Jorhem \& Slorach, 1988; Jorhem et al. 1995).

$\ddagger$ From National Institute of Standards and Technology, USA.

once weekly and the water and food consumption were determined. Samples from each diet were taken once weekly to check the Cd level and dietary composition. After 9 weeks the mice were weighed and killed by decapitation. Livers and kidneys were collected, weighed and frozen in liquid $\mathrm{N}_{2}$. The organs were kept at $-70^{\circ}$ until analysed for $\mathrm{Cd}$.

\section{Analysis of cadmium}

Processing of the samples and $\mathrm{Cd}$ analysis were performed as described by Lind et al. (1995). A Varian SpectrAA-300 atomic absorption spectrometer equipped with a Varian GTA-96 graphite furnace (Varian, Melbourne, Australia) was used for determination of $\mathrm{Cd} .{ }^{2} \mathrm{H}$ background correction and the method of standard addition were used for determining $\mathrm{Cd}$. Detection limits for the different elements were calculated to be equal to three standard deviations of the mean of a large number of blanks $(n>20)$. Three certified reference materials were analysed together with the samples: bovine liver (no. 1577b) from the National Institute of Standards and Technology, Washington, DC, USA; simulated diets A and D from The Swedish National Food Administration (Jorhem \& Slorach, 1988; Jorhem et al. 1995).

\section{Analysis of inositol phosphates}

The levels of IP6, inositol pentaphosphate (IP5), inositol tetraphosphate (IP4) and inositol triphosphate (IP3) were analysed by an HPLC method (Sandberg \& Ahderinne, 1986; Sandberg et al. 1989). This was done at the Department of Food Science, Göteborg University, Göteborg, Sweden.

\section{Statistics}

The Kruskal-Wallis one-way analysis by ranks was used when results from more than one group were compared. The Mann-Whitney $U$ test was used when results from two groups were compared. A significance level of $P<0 \cdot 05$ was used in both tests.

\section{Results}

The median body weights for the groups ranged from $14.9 \mathrm{~g}$ (sugar-beet-fibre group) to $17.2 \mathrm{~g}$ (control group; $13 \%$ difference) at the start of the experiment and from $21.2 \mathrm{~g}$ (carrot group) to $23.9 \mathrm{~g}$ (wheat-bran group; $11 \%$ difference) after 9 weeks on the different diets. In some cases, the difference in body weights was significantly different between groups (Kruskal-Wallis one-way analysis of ranks; at the start of exposure $P=0.02$, week 3 $P=0.012$, week $8 P=0.034$, week $9 P=0.006$ ), but the change in median body weight expressed as percentage weight gain each week was not significantly different between groups. The median liver and kidney weights ranged from 0.940 to $1.17 \mathrm{~g}$ (20\% difference) and from 0.255 to $0.340 \mathrm{~g}$ ( $25 \%$ difference) which was statistically significant in some cases. However, values for liver weight : body weight and kidney weight : body weight did not differ between the groups.

\section{Analytical quality control of cadmium analysis}

The analysis of the reference samples showed good agreement between our results and the certified levels (Table 4), showing that the analytical results of the present study are of satisfactory quality.

\section{Cadmium level in the diets, food consumption and cadmium intake}

When the weekly samples from each diet were analysed for $\mathrm{Cd}$ it was found that the wheat-bran diet and the diet containing $\mathrm{CdCl}_{2}$ had a statistically significant higher $\mathrm{Cd}$ level than the sugar-beet-fibre and carrot diets (Table 2). Food consumption did not differ between the groups. As a consequence, $\mathrm{Cd}$ intakes were higher for the wheatbran and $\mathrm{CdCl}_{2}$ groups compared with those of the sugarbeet-fibre group and carrot group (Table 5). 
Table 5. The total cadmium intake ( $\mu \mathrm{g} /$ animal) of mice after 9 weeks on the different diets*

\begin{tabular}{lc}
\hline Dietary group & Cd intake $(\mu \mathrm{g} /$ animal $)$ \\
\hline Control & $<2$ \\
Wheat bran & 12.8 \\
Sugar-beet fibre & 9.6 \\
Carrot & 8.7 \\
$\mathrm{CdCl}_{2}$ & 11.5 \\
\hline
\end{tabular}

${ }^{*}$ For details of diets, see p. 206 and Tables 1-3.

\section{Inositol phosphates and trace elements in the diets}

The main composition did not differ markedly between the feeds, except for the fibre content which was three to four times higher in the wheat-bran, sugar-beet-fibre, and carrot diets than in the control and $\mathrm{CdCl}_{2}$ diets. The levels of IP5 and IP6 were highest in the wheat-bran diet (Table 3). In the carrot diet, low levels of IP3, IP4 and IP6 were found and only traces of IP5. The sugar-beet-fibre diet only contained low levels of IP3 and IP4. The levels of IP3 and IP4 were comparable in the sugar-beet-fibre and carrot diets. The control and $\mathrm{CdCl}_{2}$ diets contained no detectable inositol phosphates (Table 3).

The $\mathrm{Zn}$ level of the wheat-bran diet was about twice as high as those of the other diets (except the carrot diet; Table 2). The $\mathrm{Zn}$ level of the carrot diet was also significantly higher $(25-30 \%)$ than those of the sugar-beet-fibre and $\mathrm{CdCl}_{2}$ diets. The $\mathrm{Ca}$ level of the wheat-bran diet was, on the other hand, significantly lower (15-30\%) than those of the other diets. For the other trace elements, the differences in levels between the diets were small, although statistically significant in some cases.

\section{Cadmium content of liver and kidneys}

The median Cd content in the liver and kidneys and the ratio between the $\mathrm{Cd}$ contents in these organs are shown in Table 6. As the Cd intake was different among the groups due to differences in the $\mathrm{Cd}$ level of the diets, the fractional accumulation (\% total $\mathrm{Cd}$ intake) in the liver and kidneys was calculated. The fractional accumulation of $\mathrm{Cd}$ in the liver of the wheat-bran group was significantly lower (20-30\%) when compared with values for the other groups (Table 7). Moreover, in the same group, the kidneys had a 30-35\% lower fractional accumulation of Cd compared with values for the other groups. As a consequence, the fractional accumulation in liver + kidneys was significantly lower $(25-35 \%)$ in the wheat-bran group

\section{Discussion}

The group of mice receiving $\mathrm{Cd}$ from wheat bran had a significantly lower fractional $\mathrm{Cd}$ accumulation in both the liver and kidneys compared with the other groups after 9 weeks of exposure, indicating that $\mathrm{Cd}$ in wheat bran is less

Table 6. The content of cadmium (ng) in liver and kidney and the kidney : liver value for mice after 9 weeks on the different dietsll (Values are medians and ranges for four to eight mice)

\begin{tabular}{|c|c|c|c|c|c|c|}
\hline \multicolumn{2}{|l|}{ Dietary group... } & \multirow{2}{*}{$\begin{array}{c}\text { Control } \\
3 \cdot 45^{\star} \\
2 \cdot 3-5 \cdot 24\end{array}$} & \multirow{2}{*}{$\begin{array}{l}\text { Wheat bran } \\
\begin{array}{l}14.4 \\
11.0-16.7\end{array}\end{array}$} & \multirow{2}{*}{$\begin{array}{c}\text { Sugar-beet fibre } \\
15 \cdot 3 \\
12 \cdot 0-20 \cdot 1\end{array}$} & \multirow{2}{*}{\begin{tabular}{l}
\multicolumn{1}{c}{ Carrot } \\
$12 \cdot 5 \dagger$ \\
$11.4-15.2$
\end{tabular}} & \multirow{2}{*}{$\begin{array}{c}\mathrm{CdCl}_{2} \\
17 \cdot 8 \ddagger \\
13 \cdot 0-22 \cdot 7\end{array}$} \\
\hline Liver: & $\begin{array}{l}\text { Median } \\
\text { Range }\end{array}$ & & & & & \\
\hline Kidney: & $\begin{array}{l}\text { Median } \\
\text { Range }\end{array}$ & $\begin{array}{l}4.54^{*} \\
3.5-5.76\end{array}$ & $\begin{array}{l}10 \cdot 2 \\
7 \cdot 0-14.2\end{array}$ & $\begin{array}{l}11.0 \\
5.4-11.9\end{array}$ & $\begin{array}{l}10.7 \\
7 \cdot 0-15.9\end{array}$ & $\begin{array}{l}12 \cdot 9 \\
6 \cdot 8-17 \cdot 6\end{array}$ \\
\hline Liver + kidney: & $\begin{array}{l}\text { Median } \\
\text { Range }\end{array}$ & $\begin{array}{l}7.52^{*} \\
6.74-11.0\end{array}$ & $\begin{array}{l}25 \cdot 3 \\
19 \cdot 1-30 \cdot 1\end{array}$ & $\begin{array}{l}27 \cdot 1 \\
17 \cdot 4-31 \cdot 1\end{array}$ & $\begin{array}{l}23 \cdot 5 \\
19 \cdot 3-31.0\end{array}$ & $\begin{array}{l}33 \cdot 6 \S \\
19 \cdot 3-31 \cdot 0\end{array}$ \\
\hline Kidney: liver: & $\begin{array}{l}\text { Median } \\
\text { Range }\end{array}$ & $\begin{array}{l}1.20^{*} \\
1.05-1.93\end{array}$ & $\begin{array}{l}0.79 \\
0.48-1.01\end{array}$ & $\begin{array}{l}0.62 \\
0.42-0.79\end{array}$ & $\begin{array}{l}0.81 \\
0.57-1.15\end{array}$ & $\begin{array}{l}0.73 \\
0.52-1.01\end{array}$ \\
\hline
\end{tabular}

Median values were significantly different from those for the other groups (Mann-Whitney $U$ test): ${ }^{*} P<0.05$.

Median value was significantly different from that for the sugar-beet-fibre group (Mann-Whitney $U$ test): $† P<0.05$.

Median value was significantly different from those for the wheat-bran and carrot groups (Mann-Whitney $U$ test): $\ddagger P<0.05$.

Median value was significantly different from those for the other Cd-exposed groups (Mann-Whitney $\mathrm{U}$ test): $\S P<0.05$.

$\|$ For details of diets, see p. 206 and Tables 1-3.

Table 7. The fractional accumulation of cadmium (\% total cadmium intake) in liver, kidney and the liver + kidney combined of mice after 9 weeks on the different diets

(Values are medians and ranges for eight mice)

\begin{tabular}{|c|c|c|c|c|c|}
\hline \multicolumn{2}{|c|}{ Dietary group... } & \multirow{2}{*}{$\begin{array}{l}\text { Wheat bran } \\
0 \cdot 112^{*} \\
0 \cdot 086-0 \cdot 130\end{array}$} & \multirow{2}{*}{$\begin{array}{l}\text { Sugar-beet fibre } \\
0 \cdot 159 \\
0 \cdot 125-0.210\end{array}$} & \multirow{2}{*}{$\begin{array}{c}\text { Carrot } \\
0 \cdot 143 \\
0 \cdot 127-0 \cdot 174\end{array}$} & \multirow{2}{*}{\begin{tabular}{l}
\multicolumn{1}{c}{$\mathrm{CdCl}_{2}$} \\
$0 \cdot 154$ \\
$0 \cdot 113-0 \cdot 197$
\end{tabular}} \\
\hline Liver: & $\begin{array}{l}\text { Median } \\
\text { Range }\end{array}$ & & & & \\
\hline Kidney: & $\begin{array}{l}\text { Median } \\
\text { Range }\end{array}$ & $\begin{array}{l}0.080 \dagger \\
0.055-0.111\end{array}$ & $\begin{array}{l}0.115 \\
0.056-0.124\end{array}$ & $\begin{array}{l}0.123 \\
0.081-0.183\end{array}$ & $\begin{array}{l}0.112 \\
0.059-0.153\end{array}$ \\
\hline Liver + kidney: & $\begin{array}{l}\text { Median } \\
\text { Range }\end{array}$ & $\begin{array}{l}0 \cdot 198^{*} \\
0 \cdot 149-0.235\end{array}$ & $\begin{array}{l}0.282 \\
0 \cdot 181-0.323\end{array}$ & $\begin{array}{l}0.271 \\
0.222-0.358\end{array}$ & $\begin{array}{l}0.293 \\
0.172-0.317\end{array}$ \\
\hline
\end{tabular}

Median values were significantly different from those for the other groups (Mann-Whitney $U$ test): ${ }^{*} P<0.05$.

Median value was significantly different from those for carrot and $\mathrm{CdCl}_{2}$ groups (Mann-Whitney $U$ test): $† P<0.05$. 
available for absorption than $\mathrm{Cd}$ from the other sources used in the present study.

In mice, more than $70 \%$ of the body burden of $\mathrm{Cd}$ is found in the liver and kidneys after long-term exposure (Andersen, 1989). The elimination of absorbed Cd from mice is also very slow (Engström \& Nordberg, 1979; Nordberg et al. 1985; Andersen, 1989). The fractional Cd accumulation in the liver and kidneys, therefore, can be used as an estimate of the fractional $\mathrm{Cd}$ absorption.

The lower fractional absorption of $\mathrm{Cd}$ from wheat bran is in accordance with the findings of a study by Buhler (1985) in which rats fed on a wheat-bran diet had a lower $\mathrm{Cd}$ absorption compared with that of animals exposed to $\mathrm{Cd}$ from carrot, lettuce, soyabean, spinach and tomato. Moberg Wing (1993) also found that the fractional accumulation of Cd in liver + kidneys was 34-48\% lower in rats fed on whole-wheat or wheat-bran diets compared with rats fed on a low-fibre wheat-endosperm diet.

The wheat-bran diet differed from the other diets in more than one way. It contained high levels of IP5 and IP6, and had a significantly higher Zn level and a significantly lower $\mathrm{Ca}$ level compared with the other diets. A high level of $\mathrm{Zn}$ in the diet has been shown to negatively affect Cd absorption (Lamphere et al. 1984). However, both the $\mathrm{Zn}$ and Cd concentration used in that study were very high, and in the study of Moberg Wing (1993), where more physiological concentrations of $\mathrm{Zn}$ and $\mathrm{Cd}$ were used, $\mathrm{Zn}$ concentration did not appear to affect $\mathrm{Cd}$ absorption in rats. Both the $\mathrm{Zn}$ and $\mathrm{Cd}$ concentrations in our study were comparable to the concentrations in the study of Moberg Wing (1993).

A low concentration of $\mathrm{Ca}$ in the diet might, in some cases, increase the absorption of Cd (Larsson \& Piscator, 1971; Hamilton \& Smith, 1978; Nordberg et al. 1985). However, the variation in Ca concentrations in the diets used in our study was not very large and probably had no effect on fractional $\mathrm{Cd}$ absorption. Thus, the lower fractional absorption of $\mathrm{Cd}$ from wheat bran compared with that from the other fibre sources was probably not due to the relatively small difference in $\mathrm{Zn}$ and $\mathrm{Ca}$ levels in the diet. It is also not likely that the somewhat higher Cd content of the wheat-bran diet caused a lower fractional absorption of $\mathrm{Cd}$ by blocking $\mathrm{Cd}$ absorption in the intestinal mucosa. It has been shown in a number of studies that the fractional Cd absorption is not influenced by lumen exposure to up to $200 \mu \mathrm{M}-\mathrm{Cd}$, which is considerably higher than the exposure level in our study (Foulkes, 1980, 1985, 1989; Bevan \& Foulkes, 1989). The Cd level in the feed was 0.4-0.6 $\mu \mathrm{mol} /$ $\mathrm{kg}$. Based on the daily food consumption and the ingestion of drinking water this would result in a lumen $\mathrm{Cd}$ concentration of $<1 \mu \mathrm{M}$ (approximately $3.5 \mathrm{~g}$ feed and $4 \mathrm{ml}$ drinking water/mouse per d) assuming that all $\mathrm{Cd}$ in the food was dissolved in the stomach of the mice.

The wheat-bran diet contained high levels of both IP5 and IP6. In the carrot diet, on the other hand, IP5 and IP6 were present at very low levels and the sugar-beet-fibre and $\mathrm{CdCl}_{2}$ diets contained no detectable IP5 and IP6. An in vitro study on the effect of phytic acid on the absorption of $\mathrm{Cd}$ across the intestinal walls of rats showed that both the $\mathrm{Cd}$ absorption and retention of $\mathrm{Cd}$ in the mucosa was significantly lowered in the presence of phytic acid (Turecki et al.
1994). It has also been shown that the inhibitory influence of IP3-IP6 on the uptake and absorption of $\mathrm{Fe}$ and $\mathrm{Zn}$ in the human intestinal cell line model (Caco-2) was proportional to the phosphorylation of inositol (Han et al. 1994). In vitro studies have shown that $\mathrm{Zn}$ and $\mathrm{Fe}$ form insoluble complexes with IP5 and IP6 (Sandberg et al. 1989; Sandström \& Sandberg, 1992; Reddy et al. 1996). In contrast, IP3 and IP4 did not have any effect on Fe solubility (Sandberg et al. 1989).

Thus, the formation of insoluble complexes between $\mathrm{Cd}$ and IP5 and IP6 may be the reason for the decreased fractional absorption of $\mathrm{Cd}$ in mice exposed to the wheatbran diet. The sugar-beet-fibre, carrot and $\mathrm{CdCl}_{2}$ diets contained no detectable or very low levels of IP5 and IP6 and the fractional accumulation of $\mathrm{Cd}$ in the liver and kidneys did not differ between these groups.

There was some background exposure to $\mathrm{Cd}$, as the control group had measurable Cd levels in the liver and kidney. Although the $\mathrm{Cd}$ level of the control feed was below the detection limit, there was probably some $\mathrm{Cd}$ even in the control feed. All groups also received the same drinking water, which contained very low but measurable levels of $\mathrm{Cd}(0.02-0.03 \mu \mathrm{g} / \mathrm{l})$. The mice in the present study were newly weaned when they arrived, but it is possible that they had received standard rat feed for some days before they came to our laboratory. An analysis of one type of rat pellets frequently used, R36 (Astra Ewos, Södertälje, Sweden), showed that this feed contained $0.06 \mathrm{mg} \mathrm{Cd} / \mathrm{kg}$ (Y Lind, J Engman, L Jorhem and A Wicklund Glynn, unpublished results). The kidney: liver value for $\mathrm{Cd}$ in the control group was almost twice as high as that in the $\mathrm{Cd}$-exposed groups. This indicates that the background $\mathrm{Cd}$ exposure mostly occurred before the start of the experiment, since absorbed $\mathrm{Cd}$ is slowly distributed from the liver to the kidneys (Piscator, 1964; Webb, 1979).

All the Cd-exposed groups had a $\mathrm{Cd}$ content in the liver + kidneys that was more than three times higher than that of the control group. This shows that the differences in $\mathrm{Cd}$ content of liver and kidneys in the Cd-exposed groups is due to differences in fractional absorption of $\mathrm{Cd}$ during the experimental period.

Sugar-beet fibre has been proposed as an alternative to wheat bran as a dietary fibre source due to the lack of negative effects of sugar-beet fibre on the intestinal absorption of mineral elements (Fairweather-Tait \& Wright, 1990). Our study shows that commercial preparations of sugar-beet fibre may contain high levels of $\mathrm{Cd}(0.65 \mathrm{mg}$ $\mathrm{Cd} / \mathrm{kg}$ ) that are more easily absorbed than $\mathrm{Cd}$ from wheat bran. If sugar-beet fibre with the $\mathrm{Cd}$ level found in our study $(0.65 \mathrm{mg} \mathrm{Cd} / \mathrm{kg})$ is used in bread baked according to the recipe on the sugar-beet fibre package, and an average of $90 \mathrm{~g}$ bread is consumed daily (HULK, 1994), this will result in an additional intake of 3-4 $\mu \mathrm{g} \mathrm{Cd} / \mathrm{d}$ from sugarbeet fibre. The daily $\mathrm{Cd}$ intake in Swedish women has been estimated to be 10-22 $\mu \mathrm{g}$ (Vather et al. 1996), which indicates that the use of sugar-beet fibre in baking may significantly contribute to the daily intake of $\mathrm{Cd}$.

If the same calculations are made on the intake of $\mathrm{Cd}$ from wheat bran with the $\mathrm{Cd}$ level found in the present study $(0.31 \mathrm{mg} \mathrm{Cd} / \mathrm{kg})$, assuming that wheat bran is used instead of sugar-beet fibre in the bread, this will result in an 
additional $\mathrm{Cd}$ intake of $1-2 \mu \mathrm{g} \mathrm{Cd} / \mathrm{d}$ from wheat bran. It should be pointed out, however, that the $\mathrm{Cd}$ level in the wheat bran used in the present study was about three times higher than that normally found in wheat bran on the Swedish market (Jorhem et al. 1984).

Using the Cd levels of the carrots found in our study (approximately $0.046 \mathrm{mg} \mathrm{Cd} / \mathrm{kg}$ wet weight), which is not an unusual Cd level for carrots on the Swedish market (Jorhem et al. 1984; Jansson \& Öborn, 1995), and an average consumption of root crops (including carrots) of $10 \mathrm{~g} / \mathrm{d}$ in Sweden (HULK, 1994), the Cd intake would be six to eight times lower $(0.5 \mu \mathrm{g} / \mathrm{d})$ than that from sugar-beet fibre. However, the $\mathrm{Cd}$ level of carrots should not be allowed to increase, since high carrot consumption may result in significant contributions to the daily $\mathrm{Cd}$ intake.

Our study indicates that in mice the $\mathrm{Cd}$ absorption from sugar-beet fibre, carrots and $\mathrm{CdCl}_{2}$ is higher than that of $\mathrm{Cd}$ from wheat bran. This difference in absorption is most likely to be dependent on the presence of different inositol phosphates in sugar-beet fibre and carrots compared with wheat bran. However, further investigations of the influence of different inositol forms on the absorption of $\mathrm{Cd}$, in the absence of other factors that influence $\mathrm{Cd}$ absorption, such as $\mathrm{Ca}$ and $\mathrm{Zn}$, are needed before firm conclusions can be drawn. Moreover, the effect of wheat bran on Cd absorption from other diets would be of interest for further studies.

The intake of $\mathrm{Cd}$ from sugar-beet fibre may significantly contribute to the daily $\mathrm{Cd}$ intake, especially in cases of high consumption of bread containing sugar-beet fibre. The $\mathrm{Cd}$ intake from carrots and wheat bran could also be significant in cases of a high consumption of these foodstuffs. As consumption of these foodstuffs also may be positive to human health, it is important that the Cd levels are kept low.

\section{Acknowledgements}

The authors wish to thank Dagmar Brabencova and Lena Carlsson for help with the animals during the experiment and Ingrid Öborn (The Swedish University of Agricultural Sciences, Uppsala, Sweden) for providing the carrots. The study was financed by the Swedish National Protection Agency (grant no. 32519), the Foundation of Agricultural Research (grant no. 945907) and the Foundation of Cerealia.

\section{References}

Andersen O (1989) Oral cadmium exposure in mice: toxicokinetics and efficiency of chelating agents. Critical Reviews in Toxicology 20, 83-112.

Andersson A \& Bingefors S (1985) Trends and annual variation in $\mathrm{Cd}$ concentrations in Swedish wheat and barley. Archives of Environmental Health 30, 321-328.

Andersson A \& Siman G (1991) Levels of Cd and some other trace elements in soils and crops as influenced by lime and fertilizer level. Acta Agriculturae Scandinavica 41, 3-11.

Berglund M, Åkesson A, Nermell B \& Vather M (1994) Intestinal absorption of dietary cadmium in women depends on body iron stores and fibre intake. Environmental Health Perspectives 102, 1058-1065.

Bevan C \& Foulkes EC (1989) Interactions of cadmium with brush border membrane vesicles from the rat small intestine. Toxicology 54, 297-309.
Buhler DR (1985) Availability of cadmium from foods and water. Advanced Modern Environmental Toxicology 9, 271-287.

Engström B \& Nordberg GF (1979) Dose dependence of gastrointestinal absorption and biological half-time of cadmium in mice. Toxicology 13, 215-222.

Fairweather-Tait SJ \& Wright AJA (1990) The effect of sugar-beet fibre and wheat bran on iron and zinc absorption in rats. British Journal of Nutrition 64, 547-552.

Foulkes EC (1980) Some determinants of intestinal cadmium transport in the rat. Journal of Environmental Pathology and Toxicology 3, 471-481.

Foulkes EC (1985) Interactions between metals in the rat jejunum: implications of the nature of cadmium uptake. Toxicology 37, $117-125$.

Foulkes EC (1989) On the mechanism of cellular cadmium uptake. Biological Trace Element Research 21, 195-200.

Hamilton DL \& Smith MW (1978) Inhibition of intestinal calcium uptake by cadmium and the effect of a low calcium diet on cadmium retention. Environmental Research 15, 175-184.

Han O, Failla ML, Hill AD, Morris ER \& Smith JC Jr (1994) Inositol phosphates inhibit uptake and transport of iron and zinc by a human intestinal cell line. Journal of Nutrition 124, 580-587.

HULK (1994) Hushållen livsmedelsutgifter och kostvanor (Food Habits and Nutrient Intake in Sweden 1989). Uppsala, Sweden: The Swedish National Food Administration.

Jansson G \& Öborn I (1995) Kadmium i mark och morötter resultat från provtagningar 1993 och 1994 (Cadmium in the Ground and in Carrots - Results from Taking of Specimens 1993 and 1994). The Swedish National Food Administration Report no. 18/95. Uppsala, Sweden: The Swedish National Food Administration.

Jorhem L, Mattson P \& Slorach S (1984) Lead, cadmium, zinc and certain other metals in food on the Swedish market. Vår Föda 36, Suppl. 3, 135-208.

Jorhem L \& Slorach S (1988) Design and use of quality control samples in a collaborative study of trace metals in the daily diet. Fresenius Zeitschrift für Analytische Chemie 332, 738-740.

Jorhem L, Slorach S, Engman J, Schröder T \& Johansson M (1995) The Establishment of Certified Concentrations of Thirteen Elements in Six Simulated Diet Reference Materials. The Swedish National Food Administration Report no. 4/95. Uppsala, Sweden: The Swedish National Food Administration.

Kjellström T, Lind B, Linnman L \& Elinder C-G (1975) Variation of Cd concentrations in Swedish wheat and barley. Archives of Environmental Health 30, 321-328.

Kratzer FH \& Vohra P (1986) Chelates in Nutrition. Boca Raton, FL: CRC Press Inc.

Lamphere DN, Dorn CR, Reddy CS \& Meyer AW (1984) Reduced cadmium body burden in cadmium exposed calves fed supplemental zinc. Environmental Research 33, 119-129.

Larsson S-E \& Piscator M (1971) Effect of cadmium on skeletal tissue in normal and in calcium-deficient rats. Israeli Journal of Medical Science 7, 495-497.

Lind Y, Wicklund Glynn A, Engman J \& Jorhem L (1995) Bioavailability of cadmium from crab hepatopancreas and mushroom in relation to inorganic cadmium: A 9-week feeding study in mice. Food and Chemical Toxicology 33, 667-673.

Moberg Wing A-C (1993) The effect of whole wheat, wheat bran and zinc in the diet on the absorption and accumulation of cadmium in rats. British Journal of Nutrition 69, 199-209.

Nilsson J \& Wallgren B (1987) Kadmium i miljön bedömningsgrunder (Cadmium in the Environment - Basis for Forming an Assessment). The Swedish National Environmental Protection Agency Report no. 3317. Solna, Sweden: Modin-tryck.

Nordberg GF, Kjellström T \& Nordberg M (1985) Kinetics and metabolism. In Cadmium and Health: A Toxicological and 
Epidemiological Appraisal, vol. 1 and 2, pp. 103-179 [L Friberg, C-G Elinder, T Kjellström and G-F Nordberg, editors]. Boca Raton, FL: CRC Press.

Piscator M (1964) Cadmium in the kidneys of normal human beings and the isolation from liver of rabbits exposed to cadmium. Nordisk Hygienisk Tidskrift 45, 76-82.

Reddy MB, Hurell RF, Juillerat MA \& Cook JD (1996) The influence of different protein sources on phytate inhibition of nonheme-iron absorption in humans. American Journal of Clinical Nutrition 63, 203-207.

Sandberg A-S \& Ahderinne R (1986) HPLC method for determination of inositol tri-, tetra-, penta- and hexaphosphates in foods and intestinal contents. Journal of Food Science 51, $547-550$.

Sandberg A-S, Carlsson N-G \& Svanberg U (1989) Effects of inositol tri-, tetra-, penta- and hexaphosphates on in vitro estimation of iron availability. Journal of Food Science 54, 159-161.

Sandström B \& Sandberg AS (1992) Inhibitory effects of isolated inositol phosphates on zinc absorption in humans. Journal of Trace Elements and Electrolytes in Health and Disease 6, 99-103.

Turecki T, Ewan RC \& Stahr HM (1994) Effect of phytic acid and calcium on the intestinal absorption of cadmium in vitro. Bulletin of Environmental Contamination Toxicology 53, 464-470.

Vather M, Berglund M, Nermell B \& Åkesson A (1996) Bioavailability of cadmium from shellfish and mixed diet in women. Toxicology and Applied Pharmacology 136, 332-341.

Webb M (editor) (1979) The metallothioneins. In The Chemistry, Biochemistry and Biology of Cadmium, pp. 195-266. Amsterdam: Elsevier/North-Holland. 